\title{
DETERMINANTS OF BANKING CRISIS: THE CASE OF VIETNAM
}

\author{
Luong Duy Quang \\ Ho Chi Minh City Open University \\ Email: quang.ld@ou.edu.vn
}

(Received: 09/06/2015; Revised: 07/08/2015; Accepted: 07/12/2015)

\begin{abstract}
This paper identifies determinants associated with probability of banking crisis in Vietnam. By using data sample of more than 30 commercial banks from 2005 to 2013, the results from our multivariate logit model indicate that banking crisis tends to erupt as non-performing loans, borrowings from government and State bank of Vietnam are high. Moreover, we also find that most risk in Vietnam's banking sector from period 2005-2013 lies in private commercial bank which is highly manipulated by large shareholders.
\end{abstract}

Keywords: Banking crisis, bank manipulation, event method, large shareholders, Vietnam.

\section{Introduction}

The banking crises that erupted in the US in 2007 are the latest in the series of such episodes that have been experienced by economies in various regions of the world in recent years. In the 1990 s, banking crises occurred in Europe (the 1992-93 crises in the European Monetary System's exchange rate mechanism), Latin America (the middle of 1990s), as well as in East Asia (the 1997-98 crises in Indonesia, Korea, Malaysia, the Philippine, and Thailand). These crises have been costly in varying degrees both in lost output and in the fiscal expense to rescue financial sectors.

In Vietnam, the term "banking crisis" has become familiar to people in recent years. Before 2008, Vietnam banking sector is recognized as one of the most increasingly developed industries. However, from beginning of 2008, picture of the banking system get worse and in the period of 20082012 the banking system has experienced the most destructive period than ever before with series of unexpected scenarios of banking crisis including nonperforming loans, liquidity shortage, low profitability, and poor corporate governance and risk management practices.

In wake of the crisis in 2008, the need to understand more about determinants of the Vietnam banking crisis has become more critical than ever before. Accessing this question is quite significant because it does not merely help authorities have confident base for their policies making process but it is also necessary to build up an early warning system (EWS) so that the crisis can be prevented beforehand. In recent years, several studies about financial topics in Vietnam have been done such as Ngo (2010), Huy (2013a), and Huy (2013b), etc. However, there is no paper aiming at building up EWS for the banking system in Vietnam. This paper, thus, will focus on examining theoretical paths that lead to the occurrence of banking crisis. Then, an early warning system is developed to deal with crisis.

\section{Literature review}

\subsection{Banking crisis definition}

Effects of banking crisis are always huge 
and costly to resolve. Despite economies may experience different kinds of crisis, one thing ruled out is that if the collective effects of financial collapse is large enough, the government is forced to intervene. Therefore, Ergungor and Thomson (2005), as cited by Caprio and Klingebiel (1996), suggest that when central bankers think that a particular shock to the financial system could develop into a systemic problem, and the monetary authorities begin to respond, banking system is considered as crisis. In other words, banking crisis can be defined in terms of behaviours of central banks. Kaminsky and Reinhart (1996) share this perspective in his study by clarifying two policies of the central bank in the crisis period. Under this view, banking crisis links closely with two types of events (1) bank runs that lead to the closure, merging, or takeover by the public sector of one or more financial institutions (as in Venezuela in 1993); and (2) if there are no runs, the closure, merging, takeover, or largescale government assistance of an important financial institution (or group of institutions) that marks the start of a string of similar outcomes for other financial institutions. As discussed by Kaminsky and Reinhart (1996), such event-based approach is not without drawbacks. It could date the crises too late, because the financial problems usually begin well before a bank is finally closed or merged; it could also date the crises too early because the worst of crisis may come later. Moreover, the data of banking crisis in terms of their approach is available at limited level. Kaminsky and Reinhart (1996) just list system banking crisis of more than 20 countries. This makes it harder for researchers to expand the scope of study. In another study, Gonzalez et al (1997) use the intervention policy of the Central Bank as signal to identify banking crisis. And more recently, in a study published in 2009, Bagatiuk and Dzhamalova (2009) define the banks revoked license or under special supervision of the Central Bank or the debt management agency are in a crisis stage. Overall this is a fairly common method and is applied widely in academic research in the field of banking crisis.

Parallel to the event method, some researchers as Kibritcioglu (2003), Hagen and Ho (2007) have developed technical indicators to identify the banking crisis. The idea behind this method is that the index is designed to measure the level of liquidity in the banking system. One of an example for this technique is index of money market pressure. This index is published in Jürgen von Hagen and Kuang Tai-Ho's study about banking crisis in 2007. The rationale for this index is based on the behavior of central banks in the pre-crisis period. Accordingly, Hagen and Ho (2007) suggested that the liquidity of commercial banks decrease (due to bad debt is too high or withdrawal phenomena series), central banks will directly intervene in the market currency by two measures. First, the increasing required reserves to meet the liquidity needs of the commercial banks. Second, allowing shortterm interest rate changes to match temporary liquidity in the system. Based on this idea, Hagen and Ho (2007) have established indicators of currency market pressure by measuring the oscillations of required reserves and interest rates during the crisis period. According to Hagen and Ho (2007), the higher market pressure index becomes the lower liquidity of monetary system is. This is a signal to warn an upcoming crisis.

Based on the above discussion, there may have two main methods for measuring crisis including event and index method. Index method has a favourable advantage of being able to measure the level of liquidity, and thus can more accurately measure the time of crisis. However, this method is only suitable for the researches at national level. This is a drawback if the researchers want to study the 
crisis at bank-sector level. Meanwhile, the method of event completely does not deal with this limitation, and is flexibly applied in all of the cases. Therefore, the author believes that the event-methods suite well to the objectives of this study.

\subsection{The events to identify the banking crises in Viet Nam}

The events related to the crisis are an important signal for identifying crisis bank as well as the time of the crisis. The problem is that these events are quite diverse and each country depending on the circumstances or specific conditions will have the different events (policy, program or action) responding to the crisis. So the question is what kinds of the event will be used as the basis for determining the crisis in the case of Vietnam? The authors believe that this question can be answered through Dziobeck and Pazarbasioglu (1998)'s study. In this study, the authors made a survey of the crisis response policies in 24 countries (4 developed countries, 15 developing countries and 5 economies in transition). The results showed that there are 13 different types of policy are often used for the crisis response, in that 4 types of policy that can be used to identify banking crisis in Vietnam in the period 2005-2013.

Liquidity support from the government, central bank: As soon as the system encounters a problem, one of solutions that the central bank can apply immediately is to establish the emergency loans to support problematic banks. According to Hawkins and Turner (1999), this is because if the central bank does not intervene, the crisis will spread to other banks. More seriously, the crisis can break the credit relationship in the economy. In such case, the bank will not be able to continue funding for current projects or require a very high interest rate that businesses cannot borrow. However, it has been suggested that the central bank liquidity support for the weak banks is not a cost- effective solution because the bailout loans would create moral hazard problem and create incentives for these banks conducting more risky behaviours. In addition, the closure of weak banks will make the business environment better when the system remains the only good bank (Hawkins and Turner, 1999). Yet, despite the mixed debate, liquidity support from the government, the central bank is still one of the most popular ways applied at many crisis nations. Statistics of Dziobeck and Pazarbasioglu (1998) showed that $75 \%$ of the nation in the survey has applied this method. In this paper, any banks receive liquidity support over $50 \%$ its capital would be identified as crisis.

Establishment of nonperforming-loan management unit: Another method is also quite popular in the bank-restructuring program is establishment of third party to buy back non-performing loans of the crisis banks. According to Hawkins and Turner (1999), the involvement of a third party in nonperforming loan management is necessary because of psychological effects occurring in board director of the bank during the crisis period. In this period, the board director is often reluctant to funding new borrowing projects. This could make capital markets become less effective when the new projects cannot get credit support. More seriously, the system may deal with rollover risk. This will make the system deepen in a more serious crisis. Therefore, Hawkins and Turner (1999) indicate that the transfer of management of non-performing loans is necessary in crisis period.

Taking over the crisis bank: This measure aims at changing the Executive Board in the crisis bank. Similar to establishment of nonperforming-loan management unit, the reason for applying this approach also originate from the apprehension of the Central Bank about the risky behaviours of the Executive Board during the crisis period. 
However, unlike solutions discussed above, this approach aims at changing the entire management of the banking crisis, which completely eliminates the risk that may occur from the old Executive Board. In Vietnam, taking over the crisis bank occurs with transferring the ownership of commercial crisis banks to the Central Bank or a third other party.

Consolidation of crisis banks: Consolidation is a solution that often used in countries occurring crisis. Statistics of Dziobeck and Pazarbasioglu (1998) showed that $75 \%$ of the surveyed countries apply this method to solve the crisis. The philosophy behind is that a combination (usually strong banks and inefficiency banks) will allow to improve the efficiency of the whole system in general because the weak banks will receive support from larger banks. In addition, Hawkins and Turner (1999) also indicate that the bank merged with the strong ones not only allows improving the quality of management, the level of technology that benefits from the strong banks, but also mitigating nonperforming loans from the weak banks. Besides, the combination does not only necessarily occur among local banks. In fact, it can also occur between domestic banks and foreign banks. Hawkins and Turner (1999) recognize the foreign banks are less related to risky loans, foreign banks can increase the competitiveness of domestic banks by applying experience, new technologies and support local banks in accessing the international capital market.

Table 1. List of crisis banks in Vietnam period 2005-2013

\begin{tabular}{|c|c|c|c|c|}
\hline No & BANKS' NAME & $\begin{array}{l}\text { CRISIS } \\
\text { PERIOD }\end{array}$ & $\begin{array}{l}\text { CRISIS } \\
\text { EVENT }\end{array}$ & DETAIL \\
\hline 01 & $\begin{array}{l}\text { Vietnam Bank for Agriculture } \\
\text { and Rural Development } \\
\text { (Agribank) }\end{array}$ & 2009-2012 & $\begin{array}{l}\text { Central bank's } \\
\text { supervision }\end{array}$ & $\begin{array}{l}\text { According to the government } \\
\text { inspector conclusion (No. 18/TB- } \\
\text { TTCP), from 2009-2012, } \\
\text { Agribank's the non-performing } \\
\text { loan is up to } 12.71 \% \text {. }\end{array}$ \\
\hline 02 & $\begin{array}{l}\text { North Asia Commercial Joint - } \\
\text { Stock Bank (Bac A Bank) }\end{array}$ & 2011 & $\begin{array}{l}\text { Liquidity } \\
\text { support }\end{array}$ & $\begin{array}{l}\text { On } 28 / 10 / 2011 \text {, BIDV signed an } \\
\text { agreement of } 3000 \text { billion and }\end{array}$ \\
\hline $\mathbf{0 3}$ & Global Petro Bank (GP Bank) & 2011 & Takeover & $\begin{array}{l}5000 \text { billion to support liquidity } \\
\text { commitments to Bac A and } \\
\text { Bank GP Bank. }\end{array}$ \\
\hline 04 & 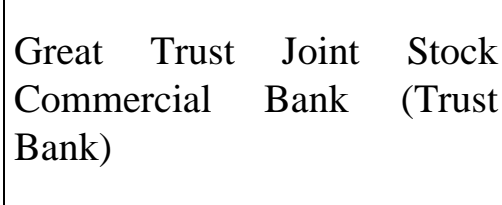 & 2012 & $\begin{array}{c}\text { Liquidity } \\
\text { support, } \\
\text { Consolidation }\end{array}$ & $\begin{array}{l}\text { On } 05 / 23 / 2013 \text {, Trust bank was } \\
\text { renamed Vietnam JSB Building. } \\
\text { This bank is also subject to the } \\
\text { State Bank's restructuring plan.. }\end{array}$ \\
\hline 05 & $\begin{array}{lr}\text { First } & \text { Joint } \\
\text { Bank_Ficombank }\end{array}$ & 2011 & \multirow{3}{*}{$\begin{array}{c}\text { Liquidity } \\
\text { support, } \\
\text { Consolidation }\end{array}$} & \multirow{3}{*}{$\begin{array}{l}\text { All } 3 \text { banks are } 3 \text { weak banks in } \\
\text { the list } 9 \text { banks must be merged. } \\
3 \text { banks were merged into one } \\
\text { and take common name Saigon } \\
\text { Commercial Bank (SCB). SCB } \\
\text { officially operating since } \\
1 / 1 / 2012 \text {. The scheme of merger } \\
\text { of three banks was supported by } \\
\text { BIDV and the State Bank. Both }\end{array}$} \\
\hline 06 & Saigon Comercial Bank_SCB & 2011 & & \\
\hline 07 & \begin{tabular}{|lcr} 
Vietnam & Tin & Nghia \\
Commercial & Joint & Stock \\
Bank_Tinnghia Bank &
\end{tabular} & 2011 & & \\
\hline
\end{tabular}




\begin{tabular}{|c|c|c|c|c|}
\hline & & & & $\begin{array}{l}2 \text { units provide a } 2400 \text { billion } \\
\text { aid package to help } 3 \text { banks to } \\
\text { solve the problem of liquidity. }\end{array}$ \\
\hline 08 & $\begin{array}{l}\text { Hanoi Building Joint-Stock } \\
\text { Commercial Bank_Habubank }\end{array}$ & 2011 & Consolidation & $\begin{array}{l}\text { This bank is also subject to the } \\
\text { Central bank's restructuring } \\
\text { plan. Habubank officially } \\
\text { merged into Saigon-Hanoi Bank } \\
\text { on 08/28/2012. }\end{array}$ \\
\hline 09 & $\begin{array}{lcc}\text { Mekong } & \text { Development } & \text { Joint } \\
\text { Stock } & \text { Commercial } & \text { Bank } \\
\text { _MDB } & & \end{array}$ & 2013 & Consolidation & $\begin{array}{l}\text { On } 15 / 04 / 2014, \text { MDB shareholders } \\
\text { meeting approved the merger plan } \\
\text { with Maritime Bank. }\end{array}$ \\
\hline 10 & $\begin{array}{l}\text { Nam Viet Joint Stock } \\
\text { Commercial Bank_Navibank }\end{array}$ & 2012 & Takeover & $\begin{array}{l}\text { Navibank bank is subject to } \\
\text { Central Bank's restructuring } \\
\text { plan. NPLs of Navibank started } \\
\text { rising May 2012. In june 2012, } \\
\text { State Bank allows the bank } \\
\text { restructured itself by its own } \\
\text { resources without merging with } \\
\text { other banks. }\end{array}$ \\
\hline 11 & 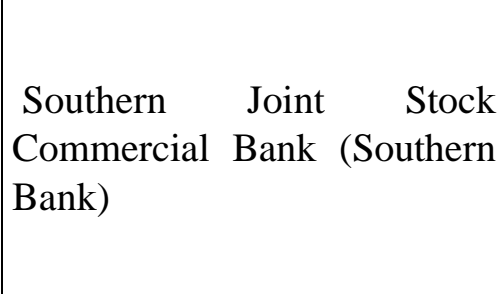 & 2013 & Consolidation & $\begin{array}{l}\text { On } 25 / 03 / 2014 \text {, Sacombank's } \\
\text { the Annual General Meeting } \\
\text { agrees merger proposals with } \\
\text { Southern Bank. This is result of } \\
\text { rising non-performing loans in } \\
\text { Southern Bank }\end{array}$ \\
\hline 12 & $\begin{array}{llr}\text { Western } & \text { Joint } & \text { Stock } \\
\text { Commercial } & \text { Bank } & \text { (Western } \\
\text { Bank) } & & \end{array}$ & 2012 & $\begin{array}{l}\text { Central bank's } \\
\text { supervision, } \\
\text { Consolidation }\end{array}$ & $\begin{array}{l}\text { On 8/09/2013, Western } \\
\text { commercial banks officially } \\
\text { merged into Petro Vietnam } \\
\text { Finance Company (PVFC). This } \\
\text { merger formed Pvcombank. This } \\
\text { bank is also subject to the State } \\
\text { Bank's restructuring plan. }\end{array}$ \\
\hline 13 & $\begin{array}{l}\text { TienPhong Commercial Joint } \\
\text { Stock Bank (Tien phong } \\
\text { bank) }\end{array}$ & 2012 & Takeover & $\begin{array}{l}\text { In 2012, Tien Phong Bank was } \\
\text { acquired by } 2 \text { corporations, } \\
\text { DOJI and Diana. This bank is } \\
\text { also subject to the State Bank's } \\
\text { restructuring plan. }\end{array}$ \\
\hline
\end{tabular}

Source: Author's collection from banks' financial statement, magazine newspapers.

\subsection{Theoretical overview of banking crisis}

This section briefly reviews theories of banking crisis that have been developed around the world to provide insight view as well as explain logic behind crisis trouble in the banking sector. Until now, a number of theories have been developed around the world and suggested hundreds of determinants for further studies. Reviewing these studies suggests some determinants that need to investigate more in case of Vietnam as followed. 
Bank capital: Bank capital has been recognized as one of the most important determinants affecting stability of banking system. Morrison and White (2005) believe that if banks' equity is large enough at the time they make their investment decisions, the bankers will decline risky behaviours. This is because if the bank starts to take risk and get loss, these losses will negatively affect economic benefits of the bank through a reduction of the bank's equity value. Morrison and White (2005) believe that this effect will effectively limit the bank's risky behaviours. On the other hand, Morrison and White (2005) also warn that if bank capital is not large enough, the bankers may be suboptimal from the point of view of society as a whole. For example, banks could make excessively risky and even negative net present value investments, which maximize the returns to equity at the expense of debt-holders or the deposit insurance fund. Moreover, in some cases, increasing bank capital too much is also not a good idea. Demirguc-Kunt et al (2010) suggest that insolvency probability becomes high as capital increases and this will create incentives for bankers to take on more risk. Therefore, it is believed that the relationship between bank capital and risk is not consistent.

Asset quality: Asset quality is the term that refers to a group of determinants that could deteriorate the asset side of bank balance sheet. In this paper, these determinants include bank size, and nonperforming loan. One of the first determinants is used to examine the relationship between asset quality and stability of banking system is bank size. According Laeven et al (2014), the relationship between risk and size of crisis banks are usually explained through two quite familiar terms including economies of scale and economies of scope. Accordingly, the larger banks often have the advantage of scope for expanding the transactions in many industries and different geographic areas. This allows banks increase profits by providing products to many more potential customers. Moreover, the diversification of activities in various fields will allow minimize risks of crisis. However, IMF (2014) also argues that size increasing in banks sometimes does not come from economies of scale or scope. This is probably the result of the phenomenon of "too big to fail". According Babanskiy (2012), in such cases, large banks tend to believe that the government will support the bank if crisis occurs. This belief will make banks more leverage and make more risky transactions.

One of the important determinants for assessing the quality of bank assets is nonperforming-loan (NPL). Overall banking crisis theories indicate that the negative impact of bad loans to the economy can be seen at two levels. At the micro level, Berger and Young (1997) identifies the impact of bad debt to the operation of the banking system is that when a loan becomes overdue, the bank increased greatly increased costs more to handle the problem. These costs include (a) the expenses for monitoring of overdue loans and the value of the collateral of the customer, b) the cost of ngotiation, c) the cost of capturing, maintaining, and finally handling collateral, d) the additional costs to protect the safety and soundness of the system, and finally, $f$ ) the diversion of senior management attention away from solving other operations problems. Karim et al (2010) believe that these expenses do not create added value for the bank, so it is obvious that once NPL rises, the bank will ineffectively operate.

Ownership: Bank's ownership structure has been recognized as an important indicator helping to predict soundness of banking system. According to Anthony et al (1990), risk-taking incentives and interest of bank managers and health of banking system are three factors that closely connected together in a cycle. In privately owned banks, if share of 
managers' wealth is largely in bank capital, they will prefer risk-averse decisions rather than risky ones because any unexpected event occurs will damage their wealth which usually considered as first cushion to absorb the loss. Therefore, in this case, the banking system is not only less likely vulnerable to shocks, but its degree of risk taking would be less than that desired by stockholders as well. However, value-maximizing manner will change if the managers hold stock or stock options in the banks. In this situation, bank managers' interest will be more closely aligned with those of stockholders and easier to take risk. In another research about ownership structure and risk-taking behavior, Yizhe et al (2013) found that not only privately owned banks but state-owned banks also deal with this phenomenon. Under their view, political pressure usually overcomes corporate profitability, and thus state-owned banks might be considered as a financial tool for high-risk and low-profit projects, but with highly social benefits.

Earning ability: Traditionally, sustained high levels of profitability would enable the bank to boost capital and improve its economic viability, thus being negatively related to the probability of failure. However, Ergungor \& Thomson (2005) argue that this logic is wrong, especially in the case the economy experience expansionary monetary policy with low interest rate. Under their view, excessive monetary growth usually comes with an increase in value of assets such as real estate, stocks, and consumer loans. Banks respond rationally to these changes by increasing their market share because increasing price of assets raise a good signal that profit on these markets is increasing while risk is falling. This tendency continues until one believes that the asset prices will continue to grow. However, as discussed by Ergungor and Thomson (2005), a long period of rising asset prices and booming credit is probably causing highly inflationary economy that creates strong incentive for the governments to intervene. In this situation, higher interest rate and restriction on loan policies are introduced to cool down the economy. As a consequence, unexpected scenarios are triggered later on such as economic growth slows down, depressing asset prices, lowering borrowers' ability to pay, increasing loan defaults, and eventually eroding banks' capital. Thus, as mentioned by Ergungor and Thomson (2005), the relationship between banking crisis and earning ability is not always like prediction of traditional theories.

\section{Proposed Research Method}

In this paper, multivariate logit model will be applied to estimate the probability of a crisis. According to Gujarati (2003), multivariate logit model is written as follows:

$$
P_{i}=E\left(Y=1 / X_{i}\right)=\frac{1}{1+e^{-\left(\beta_{1}+\beta_{2} X_{i}+\ldots+\beta_{k} X_{k}+U i\right)}}
$$

We rewrite formulation above as

$$
P_{i}=\frac{1}{1+e^{-Z i}}=\frac{e^{z}}{1+e^{z}}
$$

Where: $\mathrm{Zi}=\beta 1+\beta 2 \mathrm{X} 2+\ldots+\beta 3 \mathrm{X} 3+\mathrm{Ui}$

It is not quite difficult to verify that as $\mathrm{Zi}$ ranges $-\infty$ to $+\infty$, then $\mathrm{Pi}$ ranges between 0 and 1 and Pi nonlinearly relate to $\mathrm{Zi}$. Supposed that probability of banking crisis occurrence is $\mathrm{Pi}$, then probability of tranquility state (1-Pi) is

$$
1-P_{1}=\frac{1}{1+e^{z i}}
$$

So, we can write

$$
\frac{P_{i}}{1-P_{i}}=\frac{1+e^{Z i}}{1-e^{-Z i}}=e^{Z i}
$$

$\mathrm{Pi} /(1-\mathrm{Pi})$ is the odds ratio in favour of banking crisis appearance the ratio of the probability that one observation will experience banking crisis to the probability that it will not experience banking crisis. If we take the natural $\log$ of (3.1), we obtain:

$$
L_{i}=\ln \left(\frac{P_{i}}{1-P_{i}}\right)=Z_{i}=\beta_{1}+\beta_{2} X_{2}+\ldots+\beta_{k} X_{k}+U_{j}
$$


Based on banking crisis theory and data suggested as follows availability, our specification model is

$$
\begin{aligned}
& L_{i}=\ln \left(\frac{P_{i}}{1-P_{i}}\right)=Z_{i}=\beta_{1}+\beta_{2} C A T A+\beta_{3} N P P L s+\beta_{4} S I Z E+\beta_{5} L I Q U I D+\beta_{6} G O V_{-} \text {BORROWINGS }+ \\
& \beta_{7} \text { BANK_BORROWINGS }+\beta_{8} \text { CUSTOMER_DEPOSIT }+\beta_{9} \text { BANK_DEPOSIT }+\beta_{10} O W N E R_{-} \text {POE } \\
& +\beta_{11} R O A+\beta_{12} R O E+U_{j}
\end{aligned}
$$

In which:

CATA: total capital to total asset; NPPLs: non-performing loans; SIZE: Log of total assets of a bank; LIQUID: liquid assets including cash or balances with the State Bank to total assets; GOV_BORROWINGS: Borrowings from the government and State bank of Vietnam to total assets; BANK_BORROWINGS: Borrowings from other banks to total assets; CUSTOMER_DEPOSIT: customer deposits to total assets; BANK_DEPOSIT: Deposits from other banks to total assets; OWNER_POE: A dummy variable equal to 1 if the biggest shareholder is a private firm or individual and 0 otherwise; ROA: return on assets; ROE: return on equity

\section{Database}

Most the data of the independent variables were collected from the annual financial reports of 34 commercial banks of Vietnam for the period 2005-2013. Some other sources are also utilized to increase the amount of data as website, the prospectus, the annual shareholder meeting document of the banks. Information to determine the event of crisis is collected mainly from newspapers, magazines, financial statements of the bank.

$$
A I C=-2 \ln \left(L_{R} / L_{U R}\right)+2[(k-1)+p]=-2 \ln \left(\ln L_{R}-\ln L_{U R}\right)+2[(k-1)+p] .
$$

$\mathrm{L}_{\mathrm{UR}}$ is the maximum of likelihood function when maximized with respect to all the parameters and $L_{R}$ is the maximum when maximized with the restriction $\beta_{\mathrm{i}}=0$ for $\mathrm{i}=1,2, \ldots, \mathrm{n}$; $\mathrm{k}$ is value of dependent variables (Yi), and $\mathrm{p}$ is the number of independent variable in the model. Gujarati (2003) states

\section{Model performance and Prediction}

\section{Accuracy}

In this paper, the author use three criteria to access quality of logic model including MacFadden $\mathrm{R}$ square, likelihood ratio (LR) statistic, and Akaike information criterion (AIC). According to Gujarati (2003, p609), one of popular measure of goodness of fit is $\mathrm{R}$ square, but it does not take effect on the logit model. Therefore, Gujarati (2003, p609) provides an alternative, the MacFadden $\mathrm{R}$ square. Like $\mathrm{R}$ square, this test also ranges from 0 to 1 and it is calculated as McFadden $R-$ square $=1-\frac{L\left(\beta^{*}\right)}{L(0)} . \quad \mathrm{L}(0)$ is the value of $\log$ likelihood function when all parameters are equal to 0 and $L\left(\beta^{*}\right)$ is the value of $\log$ likelihood function has been maximized. Another test will be used in this paper is Likelihood Ratio Statistic (LRS). Gujarati (2003, p609) indicates that like F-test in linear regression, LRS is used to test null hypothesis that all slopes are equally zero. The last criterion mentioned in this part is AIC. This index helps us to compare the quality across models. The formula of this index is.

that the lower AIC becomes the better quality of unrestricted model.

\section{Results and discussion}

The main purpose of this section is to provide hypothesis test and discuss the results of the analysis. Based on the information discussed, the necessary data will be collected and 
transferred to Eview for data analysis. The table 2 summarizes the information 4 regression results about Vietnam's banking crisis. The information in the table indicates that regression
4 seems to be the best (lowest AIC, highest McFadden R-squared and statistically significant LR statistic). Thus, the results in regression 4 will be used for data analysis process.

Table 2. Regression Results

\begin{tabular}{|c|c|c|c|c|}
\hline Variables' Name & (1) & (2) & (3) & (4) \\
\hline \multicolumn{5}{|l|}{ Liquidity Variables } \\
\hline BANK_DEPOSIT & -0.052822 & -0.047252 & -0.065418 & 0.161034 \\
\hline BANK_BORROWINGS & -0.110605 & -0.111778 & -0.161133 & -0.113592 \\
\hline CUSTOMER_DEPOSIT & -0.008487 & -0.009457 & -0.023395 & $0.159980 * *$ \\
\hline GOV_BORROWINGS & $0.159027 * * *$ & $0.171736^{* * *}$ & $0.194694 * * *$ & $0.447794 * * *$ \\
\hline LIQUID & $-0.233460 *$ & $-0.415858 * * *$ & $-0.442687 * * *$ & -0.260107 \\
\hline \multicolumn{5}{|c|}{ Asset Quality Variables } \\
\hline NPPLS & - & $0.489846 * * *$ & $0.446813 * * *$ & $0.614207 * * *$ \\
\hline SIZE & - & -0.429222 & 0.227833 & 2.097512 \\
\hline \multicolumn{5}{|c|}{ Profitability variables } \\
\hline ROA & - & - & -0.174587 & -1.822782 \\
\hline ROE & - & - & $-0.319118 * * *$ & -0.122449 \\
\hline \multicolumn{5}{|c|}{ Ownership } \\
\hline CATA & - & - & - & $0.371149 * * *$ \\
\hline POE_OWNER & - & - & - & $2.308841 * *$ \\
\hline $\mathrm{C}$ & -0.828743 & 1.333492 & -0.035136 & -37.55455 \\
\hline Number of crisis & 15 & 15 & 15 & 14 \\
\hline Number of observations & 274 & 274 & 274 & 246 \\
\hline AIC & 0.416162 & 0.354762 & 0.310151 & 0.277510 \\
\hline Log likelihood & -51.01419 & -40.60236 & -32.49072 & -22.13367 \\
\hline LR statistic (df) & 14.28739 & 35.11105 & 51.33432 & 63.17603 \\
\hline Probability(LR stat) & 0.013883 & 0.000011 & 0.000000 & 0.000000 \\
\hline McFadden R-squared & 0.122833 & 0.301860 & 0.441336 & 0.587994 \\
\hline
\end{tabular}

Source: Author's calculation. 
Table 3. The summary of variables used in the regression

\begin{tabular}{|c|c|r|r|r|r|}
\hline Variables & Obs & Mean & Max & Min & Std. Dev. \\
\hline CRISIS & 278 & 0.053957 & 1 & 0 & 0.22634 \\
LIQUID & 277 & 4.836683 & 21.07293 & 0.176943 & 3.690949 \\
BANK_DEPOSIT & 275 & 18.04931 & 71.27709 & 0 & 14.24529 \\
BANK_BORROWINGS & 275 & 2.915839 & 53.12624 & 0 & 5.473593 \\
CUSTOMER_DEPOSIT & 277 & 54.53776 & 92.82358 & 12.24719 & 14.82951 \\
GOV_BORROWINGS & 277 & 2.448259 & 40.1918 & 0 & 4.214812 \\
NPPLS & 278 & 2.399215 & 12.46352 & 0 & 2.096304 \\
SIZE & 277 & 7.489033 & 8.7607 & 5.331107 & 0.634662 \\
ROA & 277 & 1.132676 & 4.961258 & 0 & 0.794522 \\
ROE & 277 & 9.89079 & 41.54924 & 0.214099 \\
CATA & 277 & 13.38923 & 66.07543 & 2.669802 & 9.769136 \\
POE_OWNER & 249 & 0.598394 & 1 & 0 & 0.49121 \\
\hline
\end{tabular}

Source: Author's calculation.

6.1. The quality of the Vietnam Banks' Assets: The Important Role of NPPLs

Two elements selected in order to assess asset quality of the banking system include non-performing loans (NPPLs) and asset size (Size). As discussed earlier, the two variables have the potential risks that may affect the system. The regression results in Table 2 show that NPPLs has a positive sign as expectation and get a significance level of less than $1 \%$. This confirms that relationship between NPPLs and the probability of crisis. In fact, this is not a new discovery. Many scattered studies around the world also confirm this relationship. In Vietnam, the State Bank of Vietnam also agrees with this view. Accordingly, the banks having nonperforming loans exceeds $3 \%$ are subject to implementation of restructuring by selling debt to the Vietnam Asset Management Company (VAMC). One interesting question arises is that how high is non-performing loans enough to cause crisis? This question seems not to have the exact answer. In their studies about banking crisis, Demirgüç-Kunt and Detragrache (1998) applied the threshold of $10 \%$ to indentify crisis. In Caprio and Klingebiel (1996), this figure fluctuated 5$10 \%$. What does the rational number determine a banking crisis? The author argues that we can apply the noise-signal method to build the optimal threshold for nonperforming loans ratio. Therefore, in this study, the noise-signal method ${ }^{6}$ will be used again to calculate the optimal non-performing loans ratio for Vietnam. The results are indicated in Table 4. The optimal ratio for Vietnam should be $5.5 \%$ instead of $3 \%$. 
Table 4. Thresholds for Non-Performing Loans

\begin{tabular}{|c|c|c|c|c|r|r|r|}
\hline $\begin{array}{c}\text { Thresholds } \\
(\%)\end{array}$ & $\begin{array}{c}\mathrm{A} \\
(\%)\end{array}$ & $\begin{array}{c}\mathrm{B} \\
(\%)\end{array}$ & $\begin{array}{c}\mathrm{C} \\
(\%)\end{array}$ & $\begin{array}{c}\mathrm{D} \\
(\%)\end{array}$ & $\begin{array}{c}\mathrm{B} /(\mathrm{B}+\mathrm{D}) \\
(1)\end{array}$ & $\begin{array}{c}\mathrm{A} /(\mathrm{A}+\mathrm{C}) \\
(2)\end{array}$ & $\begin{array}{c}\text { The noise-signal } \\
\text { ratio }\end{array}$ \\
\hline 0 & 1.439 & 93.165 & 0.000 & 5.396 & 0.945 & 1.000 & 0.945 \\
\hline 0,5 & 11.151 & 83.453 & 0.000 & 5.396 & 0.939 & 1.000 & 0.939 \\
\hline$\ldots$ & $\ldots$ & $\ldots$ & $\ldots$ & $\ldots$ & $\ldots$ & $\ldots$ & $\ldots$ \\
\hline 5 & 90.647 & 3.957 & 4.317 & 1.079 & 0.786 & 0.955 & 0.823 \\
\hline $\mathbf{5 , 5}$ & $\mathbf{9 1 . 0 0 7}$ & $\mathbf{3 . 5 9 7}$ & $\mathbf{4 . 3 1 7}$ & $\mathbf{1 . 0 7 9}$ & $\mathbf{0 . 7 6 9}$ & $\mathbf{0 . 9 5 5}$ & $\mathbf{0 . 8 0 6}$ \\
\hline 6 & 91.367 & 3.237 & 4.676 & 0.719 & 0.818 & 0.951 & 0.860 \\
\hline$\ldots$ & $\ldots$ & $\ldots$ & $\ldots$ & $\ldots$ & $\ldots$ & $\ldots$ & $\ldots$ \\
\hline 10 & 93.885 & 0.719 & 5.396 & 0.000 & 1.000 & 0.946 & 1.057 \\
\hline$\ldots$ & $\ldots$ & $\ldots$ & $\ldots$ & $\ldots$ & $\ldots$ & $\ldots$ & $\ldots$ \\
\hline
\end{tabular}

Source: Author's calculation.

\section{Box1: Noise-to-Signal Ratio Introduction}

This method is firstly proposed in Kaminsky and Reinhart's the study about dual crises (banking crises and currency) in 1996. The idea of this approach is establishing a threshold value for crisis-warning indicators. If the value of the indicators exceeds the allowable limits, this is a warning signal for an impending crisis. The problem is that how can we build this threshold value? Kaminsky and Reinhart (1996) have used the following way.

Let's calls $X_{t, i}$ is the value of the explanatory variables, $X_{i}$, at time $t ; X_{i}^{*}$ is the threshold value of $X_{i}$ and $S_{t, i}$ is a warning signal of the explanatory variables $\left(S_{t, i}\right.$ only has two values, 0 and 1). At time $t$, if $X_{t, i}>X_{i}^{*}$, then $S_{t, i}=1$ (the crisis occurs), if $S_{t, i}=0$ (no crisis occurs). Thus, there may be four cases that likely to happen.

\begin{tabular}{|c|c|c|}
\hline & Crisis occurs & No crisis occurs \\
\hline Signal & $\begin{array}{c}\text { A } \\
\text { Good signal }\end{array}$ & $\begin{array}{c}\text { B } \\
\text { False alarm }\end{array}$ \\
\hline \multirow{2}{*}{ No Signal } & C & D \\
& Missing signal & Good signal \\
\hline
\end{tabular}

Sources: Kaminsky and Reinhart (1996).

In which,

A: The number of observations that the explanatory variables emit warning signals and a crisis occurs (good signal).

B: The number of observations that the explanatory variables emit warning signals, but no crisis occurs (false alarm). 
C: The number of observations that the explanatory variables emit zero signals but the crisis occurs (Missing signal).

D: The number of observations that the explanatory variables emit zero signals and no crisis occurs (good signal).

\section{Noise to signal ratio $=[B /(B+D) / A /(A+C)] \min$}

In which, the numerator $[\mathrm{B} /(\mathrm{B}+\mathrm{D})]$ is the rate at which the threshold make wrong predictions, and denominator $[\mathrm{A} /(\mathrm{A}+\mathrm{C})]$ ratio threshold make right predictions. Thus, to find the optimal warning value, Kaminsky and Reinhart (1996) simply use many different levels so that the value of the indicators is the lowest.

\subsection{Quality of Liquidity: difference} between the good banks and weak banks

In this study, the authors have used 5 different factors to measure the quality of the liquidity of commercial banks including liquid assets to total assets (LIQUID), borrowings from the Government and the State Bank of Vietnam to total assets (GOV_BORROWINGS), customer deposits to total assets (CUSTOMER_DEPOSIT), Deposits from other banks (BANK_DEPOSIT) and finally borrowings from other banks to total assets (BANK_BORROWINGS). The results show that 2 out of 5 elements have statistical significance. This has given us some interesting information to explain the behaviour of banks during the crisis period.

Results in Table 2 show that LIQUID, BANK_DEPOSIT, BANK_BORROWINGS have negative sign and they are not statistically significant. This result indicates that there is not enough evidence to confirm relationship of these variables and crisis. The two remaining variables, GOV_BORROWINGS and CUSTOMER_DEPOSIT, both variables are statistically significant and have positive sign to the probability of a crisis. One interesting thing is that all five variables mentioned above are used to assess liquidity resources mobilized by banks in the crisis period. So why can only 2 out of them explain the risk of crisis? The authors believe that to
BANK_DEPOSIT, BANK_BORROWINGS, these are 2 liquidity sources that the trouble bank hardly to mobilize in crisis time. Therefore, tendency of two variables toward crisis does not clearly reveal. To LIQUID, most banks ignores this factor because in the case of crisis, the trouble banks could mobilize two other sources including GOV_BORROWINGS and CUSTOMER_DEPOSIT In fact, these sources of liquidity are the most easily ways for the weak banks to mobilize. This is due to the State Bank of Vietnam will certainly intervene for the fear of systemic default risk. On the other hand, individual customers will also be ready to provide funds for "problem" banks because their deposits are paid with high interest rates and are under the protection of the State Bank of Vietnam.

\subsection{Equity and ownership: The risk lies in the private commercial banks}

In this study, to test the relationship between the bank's capital and the risk of crisis, the writer has used two-factors involving the ratio of equity to total assets (CA_TA) and forms of ownership (POE_OWNER). Firstly, POE_OWNER has positive sign and is statistically significant at the 5\% significance level. The result conforms that the crisis probability in the private commercial bank of Vietnam (POE_OWNER $=1$ ) is higher than the crisis probability of other banks in the system (POE_OWNER $=0)$. There are 2 questions 
arising from this result including (1) the probability of crisis in the private commercial banks are high, does this also mean that the probability of crisis in the state-owned commercial banks will be lower?, and (2) Why does the probability of crisis in the private banks is higher state-owned commercial banks? For the first question, we can conclude that the state-owned commercial banks are less risky than the private commercial banks. However, one thing should be noted is that the low probability of a crisis does not mean the crisis could not happen. Theoretically, the crisis risks always exist and high or low risk depends on the macroeconomic situation and the specific conditions of each bank. For the secondary question, to find the answer the author has reviewed some recent events and noticed a pretty important thing is that most crisis banks are owned by a few large shareholders (see details in Table 5).

Table 5. Percentage of major shareholders' shareholding in some crisis banks

\begin{tabular}{|c|c|}
\hline Name & Description \\
\hline Western Bank & $\begin{array}{l}\text { According to information in the Western Bank's prospectus 2010, the } \\
\text { large shareholders (shareholders holding shares >5\%) include four } \\
\text { members (1) Mr. Huong Hoang Minh (hold 12\%), (2) Mrs. Nguyen Thi } \\
\text { Kim Thanh }(9.97 \%) \text {, (3) Saigon-Binh Dinh Energy Joint Stock } \\
\text { Company }(9.85 \%) \text { and Saigon Telecommunication Technologies Joint } \\
\text { Stock Company }(9.41 \%) \text {. The total number of shares held by major } \\
\text { shareholders accounts for over } 40 \% \text { of the total shares. One thing should } \\
\text { pay more attention is Mr. Dang Thanh Tam. He is chair man of Energy } \\
\text { Saigon-Binh Dinh company and Saigon Telecommunication } \\
\text { Technology Company. In addition, Mr. Tam is also Mrs. Nguyen Thi } \\
\text { Kim Thanh's husband. }\end{array}$ \\
\hline Navi Bank & $\begin{array}{l}\text { Information in the Navibank's } 2010 \text { prospectus indicates that Navi bank } \\
\text { has } 2 \text { large shareholders involving Saigon-Binh Dinh Energy Joint } \\
\text { Stock Company (hold } 9.95 \%) \text { and JSC Shipping agents association } \\
(7 \%) \text {. Both the two companies are owned by Mr. Dang Thanh Tam. In } \\
\text { addition, his family members hold a shareholding ratio that is not less } \\
\text { than } 8 \% \text { of the shares of this bank. }\end{array}$ \\
\hline Southern Bank & $\begin{array}{l}\text { According to the prospectus in } 2008,2010 \text { and Southern Bank's report } \\
\text { administration, } 2 \text { prominent shareholder groups in this bank are United } \\
\text { Overseas Bank Limited Company (Singapore) and the Tram family } \\
\text { (Tram Be, Tram Trong Ngan, Tram Thuyet Kieu). United Overseas } \\
\text { Bank Limited Company holds } 19.99 \% \text { of the share of this bank and the } \\
\text { Tram family is over } 20 \% \text {. }\end{array}$ \\
\hline
\end{tabular}

Source: Author's collection from Banks' Financial Statement, Prospectus, and financial press.

As previously mentioned, the bank owned by a few large shareholders is probably very risky. Paligorova (2010) argue that major shareholders can control the flow of money and benefit from the company that they own.
Moreover, major shareholders have the power to gather information and create pressure on broad of director to maximize their benefits. The problem will be more serious if the large shareholders just focus on their interests and 
promote the bank investing in the high-risk projects for higher profits. This will bring a lot of risk to the remaining shareholders and the system. Information from chart 1 shows that this hypothesis is possible to become true. In some private commercial banks occurring crisis, loans to related parties ${ }^{7}$ is always higher than the average. An example of this is Western Bank. In 2009, the value of loans to the related parties is up to $120 \%$ in total loans. This means that all loan funds of the West Bank are allocated to individuals or organizations that have a great impact on banks. In the next two years, this percentage decreases, but still quite high compared to the industry average. By early 2013, Western banks officially merged into Petro-Vietnam Finance Corporation. Another case is Mekong bank. In 2009, the loans to related parties are quite small. In 2010, the figure is $20 \%$ and $60 \%$ in the next two years before falling below 20\% in 2013. In 2014, Mekong officially merged into Marinetime bank.

An interesting thing in chart 1 is that 7 problematic banks that the author can collect data, only three banks whose lending rates to related parties is higher than industry average includes Navi bank, Mekong bank and Western Bank. The remaining four banks including Ficombank, Bac A Bank, Habubank and SCB, although these banks are merged or restructured later, it seems there are no signs of major shareholder's participation (loans to related parties is equivalent to the industry average). Thus, there must be another reason causing crisis in these four banks.

\section{Chart 1. Ratio of Loans for Related Parties to total loans in 7 problematic banks}

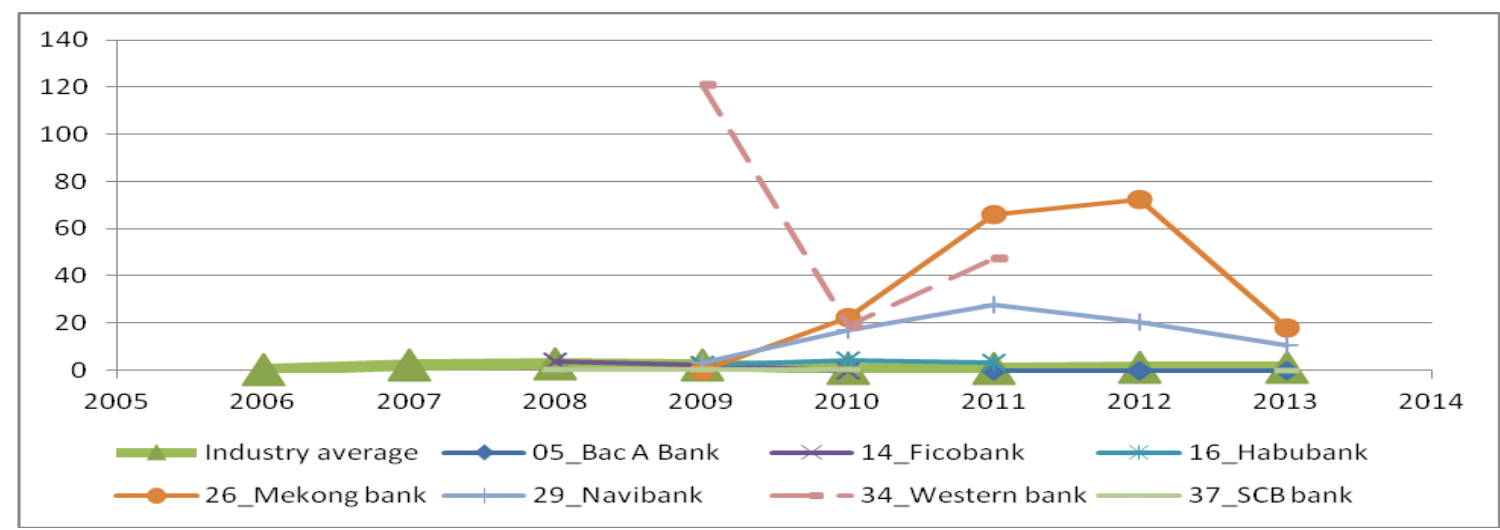

Source: Author's calculation from the banks' financial statements.

Industry average is an average of 5 largest-asset banks of Vietnam including Eximbank, Mbank, Vietcombank, Vietinbank, BIDV, and ACB.

\subsection{From the Basel I to Decree 141/2006/ND-CP: Does increasing equity reduce the risk of crisis?}

To bank regulators, capital plays a crucial role to handle and prevent crisis. This view is clearly stated in Basel I and II Accords ${ }^{8}$. The Basel Committee believes that this is an effective tool to help limit the risk of crisis. In Vietnam, using the legal capital to manage the risk of the banking system has appeared quite early. Table 5 shows that from 1988 to 2010, Vietnam has issued a lot of legal documents relating to capital of credit institutions. Prominent among them is the Decree 141/2006 /ND-CP. This decree require all the private commercial banks to raise their capital to 1,000 billion dong ( 47,8 mil USD) in 2008 and 3,000 billion dong ( $\sim 142,8$ mil USD) in 2010. One thing occurring here is that the author's statistics from the financial statements shows that by 
2008, 32 out of 38 banks meet the capital requirements of decree 141/2006 / ND-CP, account for $97.13 \%$ of the total asset value in the whole system (see in table 7). The number of commercial banks is eligible to Decree 141 is 28 , corresponding to $94.5 \%$ of the total asset value in the whole system. It could be said that this is a very impressive result because according to Ishimura (2008, p29) in the United States if applied successfully to the requirements of Basel II, the corresponding figure is only $63 \%$ of the total assets of the system. In terms of numbers, we can say that Decree 141 has been very successful, but if the plan is successful, why is there many problems occurring in Vietnam's banking system, especially in the period 2008-2013? From the results of regression analysis, the authors believe that the issue of Decree 141 that leads to the quick increase of capital combining with the lack of effective monitoring system. This has opened up opportunities for large shareholders to manipulate the banks. According to Benjamin and Michela (2014), there are 3 ways that a bank can use to increase its capital (1) the liquidation of assets to supplement the capital, (2) increasing its capital from retained earnings, and (3) issue of shares. The author argues that the banks would be afraid to implement (1) because it reduces banks' size, (2) is not attractive because this will reduce dividends to shareholders. Therefore, many banks in the period 2008-2012 issue new shares to increase its charter capital. Consequently, enabling shareholders with strong financial resources can manipulate the bank.

Table 6. Legal documents relate to the capital of the credit institutions

\begin{tabular}{|c|c|c|c|c|}
\hline 1998 & 1990 & 1996 & 1998 & 2008 \\
\hline $\begin{array}{l}\text { Decree } 53 \\
\text { HĐBT: } \\
\text { Unspecified } \\
\text { legal capital }\end{array}$ & $\begin{array}{l}\text { Ordinance banking, } \\
\text { credit cooperation, } \\
\text { financial companies: } \\
\text { Legal capital is } \\
\text { issued in beginning } \\
\text { of each financial year }\end{array}$ & $\begin{array}{lr}\text { Decision } & \text { 67/QĐ- } \\
\text { NH5: } & \text { Legal } \\
\text { capital } & \text { from } 50 \\
\text { to150 } & \text { billion } \\
\text { dong } & \end{array}$ & $\begin{array}{l}\text { Decree } \\
\text { 82/1998/NĐ-CP: } \\
\text { Legal r capital } \\
\text { from } \quad 50-70 \\
\text { billion dong }\end{array}$ & $\begin{array}{l}\text { Decree } \\
\text { 141/2006NĐ-CP: } \\
\text { Legal r capital } \\
\text { from } 1000-3000 \\
\text { billion dong }\end{array}$ \\
\hline
\end{tabular}

Source: Thảo (2010).

Table 7. Commercial banks are eligible to decree 141/2006/ND-CP in 2008 and 2010

\begin{tabular}{|c|c|c|c|c|}
\hline \multirow{2}{*}{} & \multicolumn{2}{|c|}{2008} & \multicolumn{2}{c|}{2010} \\
\cline { 2 - 5 } & $\begin{array}{c}\text { Capital <1000 } \\
\text { bill dong ( 47,8 } \\
\text { mil USD) }\end{array}$ & $\begin{array}{c}\text { Capital >1000 bill } \\
\text { dong } \\
(\sim 47,8 \text { mil USD) }\end{array}$ & $\begin{array}{c}\text { Capital <3000 } \\
\text { bill dong } \\
(\sim 142,8 \text { mil } \\
\text { USD })\end{array}$ & $\begin{array}{c}\text { Capital >3000 bill } \\
\text { dong ( 142,8 mil } \\
\text { USD })\end{array}$ \\
\hline Quantity & 6 & 32 & 11 & 28 \\
\hline $\begin{array}{c}\% \text { of the total asset } \\
\text { value to the whole } \\
\text { system }\end{array}$ & $2,83 \%$ & $97,17 \%$ & $5,5 \%$ & $94,5 \%$ \\
\hline \hline
\end{tabular}

Source: Author's calculation from the banks' financial statements. 


\section{Conclusion}

The main purpose of this research is to investigate determinants of banking crisis in Vietnam. Applying multivariate logit model in sample of 41 banks in Vietnam, the author finds that banking crisis is more likely to erupt as banks' asset quality get worse, especially when non-performing loans is high. Some other indicators such as borrowings from government, borrowings from other banks and customer's deposit are also good ones to predict the crisis. One of the most interesting findings is that probability of crisis is higher in private commercial banks than in state-owned commercial banks. This could stem from the recent capital-adjusted regulation (Decree 141/2006 /ND-CP) and the lack of effective monitoring system in Vietnam's banking system.

\section{REFERENCES}

Anthony S., Elizabeth S., \& Nickolaos G. T. (1990). Ownership Structure, deregulation, and Bank Risk Taking. The Journal of Finance, Vol. 45, No. 2.

Bagatiuk O., and Dzhamalova (2009). The Determinants of Bank Failure: the Evidence from Ukraine and Russia.

Babanskiy A. (2012). Determinats of bank failures: The case of Russia, Master thesis.

Berger, A., \& Young, R. (1997). Problem Loans and Cost of efficiency in Commercial Banks. Journal of Banking and Finance, Vol. 21, 1997.

Boot, A., W., A. (2000). Relationship Banking: What Do We Know? Journal of Financial Intermediation, Vol 9, pp. 7- 25.

Caprio, G. \& Klingebiel, D. (1996). Bank Insolvency: Bad Luck, Bad Policy, or Bad Banking?.[online]. Available at www.siteresources.worldbank.org/DEC/Resources/18701_bad_luck.pdf [accessed june 16 2009].

Costa Navajas, M., and Thegeya, A. (2013). Financial Soundness Indicators and Banking Crises, IMF Working Paper No. 13/263. Available at SSRN: http://ssrn.com/abstract=2376687.

Diamond, D.,W., \& Dybvig, P., H.(1983). Bank Run, Deposit insurance, and Liquidity, Journal of Political Economy, University of Chicago Press, vol. 91(3), pages 401-19. Available at www.minneapolisfed.org/Research/qr/qr2412.pdf, [accessed May 20 2009]

Dziobeck C. \& Pazarbasioglu. (1998). Lessons from Systemic Bank Restructuring, IMF.

Demirgüç-Kunt, A. \& Detragiache, E. (1998). The Determinants of Banking Crises in Developing and Developed Countries, IMF staff paper, 45, pp. 81-109.

Demirguc-Kunt, A., Detragiache E., \& Merrouche, O. (2010). Bank capital: lessons from the financial crisis , International Monetary Funds.

Ergungor, O., E., \& Thomson, J.,B. (2005). Systemic Banking Crises, Policies discussion papers of Federal Reserve Bank Of Cleveland.

Gonzalez-Hermosillo, B., C. Pazarbasioglu, and R. Billings (1997). Determinants of Banking System Fragility: A Case Study of Mexico, International Monetary Fund Staff Papers 44 (3), 295-314. 
Goldstein, M., Kaminsky, G., L., \& Reinhart, C. (2000). Assessing Financial Vulnerability: An Early Warning System for Emerging Markets, Institute for International Economics.

Gujarati, D., N. (2003). Basic Econometrics, $4^{\text {th }}$ ed, United States: Gary Burke.

Hagen, J., V., \& Ho,T. (2007). Money Market Pressure and the Determinants of Banking Crises, Journal of Money, Credit and Banking, Blackwell Publishing.

Hawkins J., \& Turner, P. (1999). Bank restructuring in practice: an overview, Bank for International Settlement. Policy papers, No.6, ISSN 1027-6297.

Herrero A.,G.(2005). Determinants of the Venezuelan Banking Crisis of the Mid-1990s:An Event History Analysis, MIMEO, Economía Mexicana, Vol. XIV.

Ishimura, K. (2008). The impact of the Basel II Accord on the U.S. and Japanese Financial System, USJP Occasional Paper 08-04.

Nhung, H. T., H. (2015). Developing An early Warning System to Predict Currency Crises in Emerging Markets, Vietnam-The Netherlands Programme for M.A in Development Economics, Master thesis.

Huy, D., T., N. (2013a). The Risk Level of Viet Nam Banking Industry Under Financial Leverage During and After the Global Crisis 2007-2011, Available at SSRN: http://ssrn.com/abstract=2315536.

Huy, D., T., N. (2013b). The Volatility of Viet Nam Listed Banking, Insurance and Financial Services Company Groups after the Financial Crisis 2009-2011 (October 14, 2013). Available at SSRN: http://ssrn.com/abstract=2339971 or http://dx.doi.org/10.2139/ssrn.2339971.

Kaminsky, G., \& Reinhart, C. (1996). The Twin Crises: The Causes of Banking and Balance-ofPayments Problems, International Finance Discussion Papers 544, Board of Governors of the Federal Reserve System (U.S.)

Karim, M., Z., A., Chan, S., G. \& Hassan, S. (2010). Bank Efficiency and Non-performing Loana: Evidence From Malaysia and Singapore, Prague Economic Papers.

Kibritçioglu, A. (2003). Monitoring Banking Sector Fragility, The Arab Bank R E V I E W Vol. 5, No. 2.

Molina, C. (2002). Predicting bank failures using a hazard model: the Venezuelan banking crisis, Emerging Markets Review 3, 31-50.

Morrison, A., D., \& White, L. (2005). Crisis and capital requirements in banking. American Economic Review.

Natalia, K. (2006). Probability of Bank Failure: The Russian Case, Economic Education and Research Consortium Working Paper No: 06/01.

Laeven, L., Ratnovski, L., \& Tong, H. (2014). Bank Size and Systemic Risk, available at SSRN: http://ssrn.com/abstract=2437729 
IMF. (2014). Global Financial Stability Report: Moving from Liquidity-to Growth-Driven Markets, Chapter 3: How Big Is The Implicit Subsidy For Banks Considered Too Important To Fail?, http://www.imf.org/external/pubs/FT/GFSR/2014/01/index.htm

Paligorova, T. (2010). Corporate Risk Taking and Ownership Structure, Working paper, Bank of Canada.

Thảo, P. L. N. (2010). Đánh giá khả năng các ngân hàng thương mại cổ phần đạt mục tiêu tăng vốn điều lệ theo nghị định 141/2006/ND-CP, Luận án thạc sĩ Kinh tế chương trình Fullbright.

Roberto S., M., Bulent N. G.,, Suleyman O., \& Tayyeb, S. (2005). Model of Economic and Financial Crisis, University of Pennsylvania. Available at www.luc.edu/orgs/meea/volume2/ozmucur1.pdf

Santos, J. (2000). Bank Capital Regulation in Contemporary Banking Theory: A Review of the Literature, Financial Markets, Institutions \& Instruments Volume 10, Issue 2, pages 4184, May 2001.

Yizhe D., Chao M., Michael F., Wenxuan H. (2013). Ownership structure and risk-taking: Comparative evidence from private and state-controlled banks in China.

Yibing C., Xianhua W., Lingling Z. (2013). A New Measurement of Sectoral Concentration of Credit Portfolios, First International Conference on Information Technology and Quantitative Management, Volume 17, 2013, Pages 1231-1240.

\footnotetext{
${ }^{1}$ http://www.thesaigontimes.vn/Home/taichinh/nganhang/64534/

${ }^{2}$ http://vietstock.vn/2011/12/hop-nhat-3-ngan-hang-scb-tinnghiabank-ficombank-757-208903.htm

${ }^{3}$ http://vneconomy.vn/doanh-nhan/tong-giam-doc-shb-nhin-lai-vu-sap-nhap-habubank-20130828033218856.htm

${ }^{4}$ http://kinhdoanh.vnexpress.net/tin-tuc/ebank/ngan-hang/hanh-trinh-2-nam-tai-co-cau-9-ngan-hang-yeu-kem2884626.html

${ }^{5}$ http://kinhdoanh.vnexpress.net/tin-tuc/ebank/ngan-hang/co-dong-sacombank-chap-thuan-sap-nhap-southernbank-3246842.html

${ }^{6}$ For more detail in box 1

7 According to Decision No. 234/2003/QD-BTC of December 30, 2003, related parties are defined as follow (a) enterprises that directly, or indirectly through one or more intermediaries, control, or are controlled by, or are under common control with, the reporting enterprise. (This includes holding companies, subsidiaries and fellow subsidiaries);

(b) individuals owning, directly or indirectly, an interest in the voting power of the reporting enterprise that gives them significant influence over the enterprise, and close members of the family of any such individual. Close members of the family of an individual are those that may be expected to influence, or be influenced by, that person in their dealings with the enterprise, for examples: parent, spouse, progeny, siblings, etc;

(c) Key management personnel, that is, those persons having authority and responsibility for planning, directing and controlling the activities of the reporting enterprise, including directors and officers of companies and close members of the families of such individuals; and

(d) enterprises in which a substantial interest in the voting power is owned, directly or indirectly, by any person described in (b) or (c) or over which such a person is able to exercise significant influence. This includes enterprises owned by directors or major shareholders of the reporting enterprise and enterprises that have a member of key management in common with the reporting enterprise.

${ }^{8}$ See more detail in Santos, J., 2000, Bank Capital Regulation in Contemporary Banking Theory: A Review of the Literature, Financial Markets, Institutions \& Instruments Volume 10, Issue 2, pages 41-84, May 2001.
} 